\title{
PROFESIONALITAS GURU PENDIDIKAN AGAMA ISLAM DALAM MENINGKATKAN HASIL BELAJAR PESERTA DIDIK DI MA AL-FATAH AMBON
}

\author{
Juwiti Umaternate \\ Program Studi Pendidikan Agama Islam FITK IAIN Ambon \\ E-mail: umaternatejuwiti@yahoo.com
}

\begin{abstract}
Abstrak: Guru yang profesional adalah mereka yang mengambil keahlian khusus untuk tujuan organisasi pendidikan atau sekolah guna menciptakan loncatan besar terhadap sekolah maupun terhadap peserta didik dalam pengembangan kualitas pembelajaran untuk mencapai hasil yang maksimal. Permasalahan dalam penelitian adalah bagaimana profesionalitas guru pendidikan agama islam meningkatkan hasil belajar peserta didik di MA Al-Fatah Ambon dan apa saja faktor pendudukung dan penghambat guru pendidikan agama islam meningkatkan hasil belajar peserta didik di MA Al-Fatah Ambon.

Tipe penelitian yang digunakan dalam penelitian ini yakni tipe penelitian deskriptif kualitatif dengan waktu penelitian yang dimulai dari tanggal 12 Desember 2018 sampai dengan tanggal 10 Januari 2019. Informan dalam penelitian ini adalah 4 orang dengan teknik pengumpulan data dengan cara observasi, wawancara dan dokumentasi yang kemudian dianalisi dengan menggunakan tahap reduksi data, penyajian data dan kesimpulan data.

Hasil penelitian menunjukkan profesionalitas guru pendidikan agama Islam di MA Al-Fatah Ambon digambarkan dalam kemampuan pedagogik, kemampuan kepribadian, kemampuan sosial dan kemampuan profesional, diman guru harus dapat dan kemampuan menguasai bidang studi dapat dilihat dari latar belakang pendidikan guru yang memiliki kualifikasi akademik dan latar belakang pendidikan sesuai dengan bidang tugas, kemampuan memahami peserta didik melalui pendekatan secara individual untuk mendiagnosis kesulitan dan permasalahan peserta didik sehingga. Dan selain itu untuk meningkatkan profesionalitas kinerjanya dengan mengikuti pelatihan-pelatihan, seminar, workshop. Apabila guru sudah profesional otomatis hasil peserta didik juga akan meningkat. Dengan asumsi bahwa guru yang mempunyai ketrampilan mengajar yang baik akan dapat melaksanakan proses belajar mengajar dengan baik pula. Oleh karena itu makin profesional guru yang mengajar maka makin baik pula hasil belajar peserta didik. Berkenaan dengan faktor yang mendukung profesionalitas guru pendidikan agama Islam di MA Al-Fatah Ambon adalah adanya pengawasan yang ketat dari kepala sekolah sehingga mentidakibatkan guru berdisiplin, diberlakukannya manajemen yang berbasiskan pada sekolah (MBM), terbentuknya tertib administrasi yang rapi, dan diikutkannya guru PAI dalam berbagai acara sebagai upaya peningkatan profesionalitasnya. Sedangkan hal yang menghambat profesionalitas guru di sekolah ini adalah adanya sebagian guru yang hadir di sekolah hanya pada saat-saat jam mengajar atau tidak ful time. Sehingga hal ini mengganggu guru lainnya yang lebih baik (profesional).
\end{abstract}

Kata Kunci: Profesionalitas, Guru Pendidikan Agama Islam, Hasil Belajar.

\section{PENDAHULUAN}

Pendidikan berkembang dari bentuk yang sederhana kebentuk yang sangat kompleks sejalan dengan perkembangan budaya masyarakat tempat pendidikan itu berlangsung. Dalam masyarakat yang sederhana ketika kebutuhan hidup terbatas pada hal-hal yang berhubungan dengan kelangsungan hidup pendidikan berlangsung secara intuitif dan tradisional. Pelaksanaanya ditangani sepenuhnya 
oleh orang tua. Ayah umpamannya mengajari putranya cara-cara berburu dan bercocok tanam sementara mengajari putrinya bagaimana mempersipakan makanan dan mengatur rumah.

Namun ketika kebutuhan meningkat semakin banyak, orang tidak hanya berpikir tentang bagaimana memenuhi kebutuhan itu, tetapi juga apakah perlu menciptakan kebutuhan baru, lalu memilih antara yang sesungguhnya dibutuhkan dalam hidup dan mana yang tidak dibutuhkan dalam hidup. Perkembangan bidang pekerjaan yang membawa serta spesialisasi pengetahuan dan tuntutan untuk memenuhi kebutuhan keagamaan anak membuat para orang tua sadar akan keterbatasan kemampuannya sementara kasih sayang terhadap anak mendorongnya untuk meminta bantuan para profesional dalam memikul tanggug jawab pendidikan. Pendidikan yang tadinya hanya berada dalam keluarga berkembang ke lingkungan sekolah dan lembaga pendidikan. ${ }^{1}$

Untuk itu, dapat dipahami bahwa keberadaan pendidikan bagi umat manusia sebab lewat proses pendidikanlah manusia dapat berkembang dalam kehidupannya. Akibat tuntutan kebutuhan hidup manusia maka mempengaruhi proses pelaksanaan pendidikan bagi anak didik dari waktu ke waktu yang terus berkembang di mana tadinya pelaksanaan pendidikan hanya dilaksanakan dalam keluarga lalu berpindah pada lingkungan pendidikan formal hingga adanya lembaga-lembaga pendidikan non formal dalam lingkungan masyarakat sesuai dengan sasaran dan tujuan pelaksanaan pendidikan tersebut.

Bagi umat Islam salah satu pendidikan yang tidak dapat dilepaskan dari kebutuhan hidup mereka adalah keberadaan pendidikan agama Islam yang dilaksanakan sebagai bagian dari upaya menanamkan nilai-nilai ajaran Islam bagi umat Islam agar dalam kehidupannya selalu hidup sesuai dengan nilai-nilai ajaran yang terdapat dalam agama Islam. ${ }^{2}$ Agar berhasil pelaksanaan pendidikan agama Islam yang dilaksanakan bagi peserta didiknya maka seorang pendidik dalam pendidikan agama Islam sewaktu melaksanakan kegiatan pembelajaran dituntut

\footnotetext{
${ }^{1}$ Hery Noer Aly, Ilmu Pendidikan Islam (Cet. II; Jakarta: Logos, 1999), hlm. 16

${ }^{2}$ Abdul Majid \& Dian Andayani, Pendidikan Agama Islam Berbasis Kompetensi, Konsep dan Implementasi Kurikulum 2004 (Cet. II; Bandung: PT Remaja Rosdakarya, 2005), hlm. 132
} 
memiliki kemampuan atau kompetensi terkait bidang tugasnya baik kemampuan penguasaan terhadap materi yang akan diajarkan, teknik penyampaian materi, pengoperasian media pengajaran, penerapan komunikasi yang baik dengan anak didik maupun hal-hal lain yang terkait dengan upaya peningkatan mutu anak didiknya. $^{3}$

Profesional adalah seseorang yang memiliki seperangkat pengetahuan atau keahlian yang khas dari profesinya. Ahli sosial menggunakan kata profesi untuk menunjuk pada pekerjaan yang memerlukan keahlian yang tinggi, setidaknya pengetahuan dan keahlian itu dicapai melalui kursus. ${ }^{4}$ Sedangkan dalam UndangUndang SISDIKNAS, profesional diartikan sebagai pekerjaan atau kegiatan yang dilakukan oleh seseorang dan menjadi sumber penghasilan dan kehidupan yang memerlukan keahlian, kemahiran, atau kecakapan yang memenuhi standar mutu atau norma tertentu serta memerlukan pendidikan profesi. ${ }^{5}$

Seseorang yang profesional adalah seseorang yang pekerjaannya memerlukan pelatihan dan pengalaman khusus yang lebih tinggi, tanggung jawab yang sah secara hukum, seperti lisensi untuk melakukan pekerjaan dan menentukan prestasi etika standar. Ditambah lagi bahwa berbagai survei menunjukkan bahwa seorang profesional cenderung untuk lebih berkonsentrasi terhadap etikan tanggung jawab profesionalnya dibandingkan dengan yang lainnya.

Penekanan terhadap profesional cenderung untuk memelihara dan mengikuti standar etika yang berlaku dalam masyarakat. Dihubungkan dengan profesi guru sebagai karir, maka guru yang profesional menurut Mondy adalah mereka yang mengambil keahlian khusus untuk tujuan organisasi pendidikan atau sekolah. Kemajuan ini biasanya diperoleh dari hasil pendidikan atau training khusus. Sedangkan menurut M. Uzer Usman ${ }^{6}$ guru yang profesional adalah orang yang memiliki kemampuan dan keahlian khusus dalam bidang keguruan sehingga ia

\footnotetext{
${ }^{3}$ HM. Arifin, Filsafat Pendidikan Islam (Cet. IV; Jakarta: Bumi Aksara, 2004), hlm.100

${ }^{4}$ Muktar dan A.Priambodo, Mengukir Prestasi Panduan Menjadi Guru Profesional, (Jakarta: CV. Misaka Galiza, 2001), hlm. 29.

${ }^{5}$ Departemen Agama RI, UU RI Tahun 2005 tentang Guru dan Dosen serta UU RI No.20 Thlm.2003 tentang SISDIKNAS, (Jakarta: Direktorat Jendral Pendidikan Islam, 2006), hlm. 2 hlm.19

${ }^{6}$ Mohlm. Uzer Usman, Menjadi Guru Profesional (Cet. XX; Bandung: Remaja Rosydakarya, 2006),
} 
mampu melaksanakan tugas dan fungsinya sebagai guru dengan kemampuan maksimal. Atau dengan kata lain, guru yang profesional adalah orang terdidik dan terlatih dengan baik serta memiliki pengalaman yang kaya di bidangnya.

Menurut aturan dalam UU RI No 14 Tahun 2005 tentang guru dan dosen pada penjelasan pasal 10 dikemukakan bahwa agar bisa menjalankan tugasnya dengan baik seorang guru harus memiliki kemampuan atau kompetensi meliputi; kompetensi pedagogik berupa kemampuan mengelola pembelajaran, kompetensi kepribadian berupa kemampuan kepribadian yang mantap, berakhlak mulia, arif dan berwibawa serta menjadi teladan peserta didik; kompetensi profesional berupa kemampuan penguasaan materi pelajaran secara luas dan mendalam, dan kompetensi sosial berupa kemampuan berkomunikasi dan berinteraksi secara efektif dan efisien dengan peserta didik, orang tua, sesama guru, dan masyarakat sekitar. ${ }^{7}$

Dalam Standar Nasional Pendidikan penjelasan pasal 28 ayat (3) butir c dikemukakan bahwa yang dimaksud dengan profesionalitas adalah kemampuan penguasaan materi pembelajaran secara luas dan mendalam yang memungkinkan membimbing peserta didik memiliki kompetensi yang ditetapkan dalam Standar Nasional Pendidik. Seseorang yang dikatakan profesionalitas adalah orang yang memiliki kompetensi dalam bidang yang ditekuninya dan menjadi pilihan pekerjaan

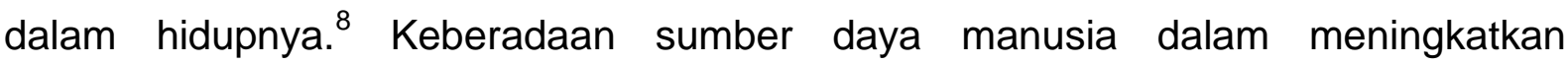
profesionalitas sangat penting. Sumber daya manusia khususnya guru PAI berperan penting dalam penanaman sikap, pengetahuan dan keterampilan, serta spiritual kepada peserta didik. Oleh karena itu, guru PAI dituntut untuk mampu menguasai materi pelajaran secara luas sehingga kemampuannya bertambah dan dapat meningkatkan profesionalitasnya.

Pengertian dasar kompetensi adalah kemampuan atau kecakapan yang menggambarkan kualifikasi atau kemampuan seseorang, baik yang kualitatif maupun yang kuantitatif. Dalam hal ini, kompetensi diartikan sebagai pengetahuan, ketrampilan, dan kemampuan yang dikuasai oleh seseorang yang telah menjadi

\footnotetext{
${ }^{7}$ Departemen Agama RI, UU RI Thlm.2005 tentang Guru dan Dosen serta UU RI No.20 Thlm.2003 tentang SISDIKNAS), hlm. 56 138.

${ }^{8}$ E. Mulyasa, Standar Kompetensi dan Sertifikasi Guru, (Bandung: PT Remaja Rosdakarya, 2007), h
} 
bagian dari dirinya, sehingga ia dapat melakukan perilaku-perilaku kognitif, afektif, dan psikomotorik dengan sebaik-baiknya. Menurut M. Uzer Usman ${ }^{9}$ menyebutkan ada dua kompetensi yang harus dimiliki guru. Pertama, kompetensi pribadi yang meliputi: (1) mengembangkan kepribadian, (2) berinteraksi dan berkomunikasi, (3) melaksanakan bimbingan dan penyuluhan, (4) melaksanakan administrasi sekolah dan, (5) melakukan penelitian sederhana untuk keperluan pengajaran. Sedangkan kompetensi Kedua yang harus dimiliki adalah kompetensi profesional yang meliputi: (1) menguasai landasan kependidikan, (2), menguasai bahan pengajaran, (3) menyusun program pengajaran, (4) melaksanakan program pengajaran dan (5) menilai proses dan hasil belajar mengajar yang telah dilaksanakan.

Kompetensi yang dimiliki oleh setiap guru akan menunjukkan kualitas guru dalam mengajar. Kompetensi tersebut akan terwujud dalam bentuk penguasaan pengetahuan dan profesional dalam menjalankan fungsinya sebagai guru. Kompetensi yang diperlukan oleh seseorang tersebut dapat diperoleh baik melalui pendidikan formal maupun pengalaman. Dengan kata lain kompetensi tidak hanya mengandung pengetahuan, ketrampilan dan sikap, namun yang penting adalah penerapan dari pengetahuan, keterampilan, dan sikap yang diperlukan tersebut dalam pekerjaan. Kompetensi merupakan ability, yaitu kapasitas seseorang individu untuk mengerjakan berbagai tugas dalam suatu pekerjaan yang mana kemampuan individu tersebut dibentuk oleh dua faktor, yaitu faktor kemampuan intelektual dan kemampuan fisik. Minimnya tenaga pengajar dalam suatu lembaga pendidikan juga memberikan celah seorang guru untuk mengajar yang tidak sesuai dengan keahliannya. Sehingga yang menjadi imbasnya adalah peserta didik sebagai anak didik tidak mendapatkan hasil pembelajaran yang maksimal. Padahal peserta didik ini adalah sasaran pendidikan yang dibentuk melalui bimbingan, keteladanan, bantuan, latihan, pengetahuan yang maksimal, kecakapan, keterampilan, nilai, sikap yang baik dari seorang guru. Oleh sebab itu, profesionalisme seorang guru menjadi harga mati untuk mencapai tujuan pembelajaran yang dicita-citakan.

${ }^{9}$ Mohlm. Uzer Usman, Menjadi Guru Profesional (Cet. XX; Bandung: Remaja Rosydakarya, 2006), 
Melihat begitu urgennya profesionalitas guru dalam upaya pembentukan prestasi belajar PAI peserta didik dalam hubunganya dengan realitas di MA Al-Fatah Ambon, maka dapat dikemukakan bahwa hanya sebagian kecil peserta didik yang kurang berprestasi pada mata pelajaran PAI sedangkan sebagian besar yang lainnya berprestasi. Dengan demikian, maka penulis tertarik untuk melakukan penelitian dengan judul "Profesionalitas Guru PAI Dalam Meningkatkan Hasil Belajar Peserta Didik di MA Al-Fatah Ambon".

\section{METODE}

Penelitian ini menggunakan motode kualitatif, dengan pendekatan deskriptif yaitu memaparkan secara mendalam dengan apa adanya secara obyektif sesuai dengan data yang dikumpulkan. Metode kualitatif sebagai prosedur penelitian yang menghasilkan data-data deskriptif yang berupa kata-kata tertulis atau lisan dari orang-orang dan perilaku yang diamati. Moleong menyatakan bahwa "penelitian kualitatif berakar pada akar alamiah sebagai keutuhan. Mengandalkan manusia sebagai alat penelitian, memanfaatkan metode kualitatif, mengadakan analisis data secara induktif, mengarahkan sasaran penelitiannya pada usaha menemukan teori dari dasar, bersifat deskriptif. ${ }^{10}$ Berdasarkan hal tersebut, maka dalam penelitian ini digunakan metode deskriptif, yaitu penelitian yang berusaha untuk menuturkan pemecahan masalah yang ada berdasarkan data-data. Di samping itu juga menyajikan data, menganalisis dan menginterprestasi, serta bersifat koperatif dan korelatif.

\section{HASIL}

\section{Profesionalitas Guru PAI Dalam Meningkatkan Hasil Belajar Peserta Didik di MA Al-Fatah Ambon}

Sebagaimana dijelaskan pada bab terdahulu bahwa profesionalitas guru terdiri dari empat pilar. Artinya apabila guru tidak memenuhi keempat pilar tersebut maka guru tersebut belum dapat atau tidak dapat disebut guru profesional, dan

\footnotetext{
${ }^{10}$ Lexy J. Moleong, Metodologi Penelitian Kualitatif, (Bandung: Remaja Rosdakarya, 2004, hlm. 4.
} 
sebaliknya jika guru dapat memenuhi atau sesuai dengan kriteria keempat pilar tersebut maka dapat dengan singkat guru tersebut termasuk guru profesional. Dan keempat pilar tersebut adalah kompetensi pedagogik, kompetensi kepribadian, kompetensi sosial dan yang terakhir adalah kompetensi profesional.

Berdasar pada uraian singkat tersebut, maka untuk mendapatkan deskripsi profesionalitas guru pendidikan agama Islam di MA Al-Fatah Ambon, digunakan wawancara atau interview kepada guru Pendidikan Agama Islam untuk lebih sistematis, maka berikut paparan temuan data di lapangan.

\section{a. Kompetensi Pedagogik}

Kompetensi pedagogik merupakan kemampuan guru dalam mengelola pembelajaran untuk menciptakan suasana belajar mengajar yang efektif dan efisien. Pengajaran pada dasarnya adalah suatu proses terjadinya interaksi antara guru dan peserta didik melalui kegiatan terpadu dari dua bentuk kegiatan yaitu kegiatan belajar peserta didik dan kegiatan mengajar guru. Oleh karena itu, guru dituntut untuk mampu atau ahli dalam hal mengelola kegiatan belajar mengajar agar tujuan pembelajaranpun dapat tercapai sesuai dengan yang diharapkan.

Untuk mendapatkan gambaran yang jelas mengenai kompetensi pedagogik guru di MA Al-Fatah Ambon, kemampuan guru dalam menyusun rencana pembelajaran, kemampuan guru dalam melaksanakan proses belajar mengajar, serta kemampuan guru melaksanakan penilaian proses belajar mengajar. Berikut ini paparan hasil penelitian mengenai kompetensi pedagogik guru pendidikan agama Islam di MA Al-Fatah Ambon.

1) Kemampuan menyusun Rencana Pelaksanaan Pembelajaran (RPP)

Guru yang baik adalah guru yang selalu berusaha sedapat mungkin agar pengajarannya berhasil. Salah satu faktor yang bisa membawa keberhasilan itu ialah guru tersebut senantiasa membuat persiapan mengajar sebelumnya. Keberhasilan guru mengelola proses belajar mengajar dapat diukur melalui kesiapan guru menciptakan pembelajaran.

Berdasarkan hasil wawancara disebutkan bahwa persiapan yang dilakukan oleh guru-guru pendidikan Agama Islam sebelum memulai pelajaran adalah sebagaimana yang diungkapkan Murni Kabalmay, S.Pd.I yaitu: 
Persiapannya seperti RPP guru harus punya, perangkat mengajar termasuk didalamnya Silabus, RPP yang harus dibuat sebelum guru memulai mengajar selain dari pada itu seorang guru juga harus menguasai materi. ${ }^{11}$

Hal serupa juga dilakukan oleh Bakri yang menyatakan bahwa:

Persiapan yang saya lakukan sebelum mengajar yaitu dengan membaca buku-buku terkait dengan materi yang akan saya ajarkan. Saya mengajar mata pelajaran PAl ya...sebelum mengajar saya banyak membaca tentang Sejarah Kebudayaan Islam dan buku-buku pendidikan agama lainnya, utamanya saya mengajar kelas VII yang dipelajari tentang Khalifatur Rasyidin dan Dinasti Bani Umayyah paling tidak saya harus menguasai materi tersebut maka terlebih dahulu saya membaca literatur-literatur mengenai, biografi serta sejarah kemajuan dan kemundurannya. Kemudian untuk penyampaian materinya saya berpedoman pada RPP dan silabus yang saya buat sebelumnya untuk rencana pembelajaran selama satu tahun. ${ }^{12}$

Selanjutnya Sauda Waliulu, mengatakan bahwa:

Kalau persiapan saya sebelum mengajar terlebih dahulu saya menyusun rencana pembelajaran dengan berpedoman pada kurikulum serta buku pelajaran. Selain dari pada itu, sebelum proses belajar mengajar terlebih dahulu saya kondisikan peserta didik-peserta didik dalam situasi yang tenang, evaluasi pelajaran yang lalu, refleksi materi pelajaran dengan menyuruh peserta didik untuk merangkum materi yang lalu serta penerapan materi pelajaran dalam kehidupan sehari-hari. ${ }^{13}$

Suciyana juga selaku guru mata pelajaran PAI menuturkan bahwa:

\footnotetext{
${ }^{11}$ Murni Kabalmay, S.Pd.I, Kepala MA Al-Fatah Ambon, Wawancara tanggal 12 Desember 2018.

${ }^{12}$ Bakri, S.Pd.I, M.Pd, Guru Pendidikan Agama Islam MA Al-Fatah Ambon, Wawancara tanggal 12 Desember 2018.

${ }^{13}$ Sauda Waliulu, S.Ag, M.Pd, Guru Pendidikan Agama Islam MA Al-Fatah Ambon, Wawancara tanggal 17 Desember 2018.
} 
Persiapan sebelum mengajar yaitu dengan melihat kurikulum, menyusun silabus, membuat program tahunan, program semester, rencana pembelajaran serta pengolahan penilaian. ${ }^{14}$

Berdasarkan pernyataan guru-guru pendidikan Agama Islam tersebut di atas jelas bahwa sebagian besar guru pendidikan agama Islam di MA Al-Fatah Ambon memiliki kemampuan menciptakan pembelajaran terbukti dari fakta di lapangan seluruh guru di MA Al-Fatah Ambon khususnya guru pendidikan agama Islam menyusun rencana pembelajaran sebelum memulai kegiatan belajar mengajar.

Dari penuturan para informan di atas, sebagaimana hasil observasi yang peneliti lakukan, peneliti melihat bahwa semua guru yang mengajar di MA Al-Fatah Ambon pada umumnya menggunakan perangkat pembelajaran berupa silabus dan RPP sebagai acuan dalam aktivitas pembelajaran di kelas. Selain itu, dalam kegiatan pembelajaran terdapat dua kegiatan yang sinergi yaitu guru mengajar dan peserta didik belajar. Guru mengajarkan bagaimana seharusnya belajar melalui berbagai pengalaman belajar hingga terjadi perubahan dalam dirinya dari aspek kognitif, psikomotor dan afektif. Persoalannya adalah bagaimana menaktifkan peserta didik agar secara sukarela tumbuh kesadaran mau dan senang belajar, maka guru harus merancang kegiatan pembelajaran yang memungkinkan peserta didik melakukan kegiatan secara aktif. ${ }^{15}$

Sebagaimana yang diungkapkan oleh Sauda Waliulu, di atas, bahwa seorang guru sebelum memulai proses belajar mengajar terlebih dahulu harus menguasai skenario pembelajaran yang tersusun dalam rancangan Silabus, RPP, Prota, Promes dan Pengolahan Penilaian.

Berdasarkan hasil wawancara tersebut di atas, maka peneliti dapat menyimpulkan bahwa kemampuan menciptakan pembelajaran sangat dibutuhkan bagi seorang guru yang berfungsi untuk:

\footnotetext{
${ }^{14}$ Suciyana, S.Pd.I, Guru Pendidikan Agama Islam MA Al-Fatah Ambon, Wawancara tanggal 17 Desember 2018.

${ }^{15}$ Hasil Observasi di MA Al-Fatah Ambon pada tanggal 17 Desember 2018.
} 
a. Memberikan pemahaman lebih jelas tentang tujuan pendidikan madrasah dan hubungannya dengan pengajaran yang dilaksanakan untuk mencapai tujuan itu.

b. Membantu guru mengenal kebutuhan-kebutuhan peserta didik, minat peserta didik dan mendorong motivasi belajar.

c. Mengurangi kegiatan yang bersifat trial and error dalam mengajar karena pembelajaran sudah terstruktur dan terencana.

d. Memberikan kesempatan bagi guru untuk memajukan pribadinya dan perkembangan profesionalnya.

2) Kemampuan melaksanakan proses belajar mengajar

Kemampuan guru dalam melaksanakan proses belajar mengajar terkadung dalam kemampuan menciptakan pembelajaran efektif, kemampuan menggunakan alat peraga dalam kegiatan belajar mengajar, kemampuan menggunakan metode yang bervariasi, kemampuan mengambil tindak lanjut, kemampuan berkomunikasi serta kemampuan mendiagnosis kesulitan belajar peserta didik, diantaranya:

a) Pelaksanakan proses belajar mengajar

Berikut ini data hasil wawancara penulis dengan guru pendidikan agama Islam terkait dengan kemampuan guru dalam melaksanakan proses belajar mengajar terkait dengan ketrampilan membuka dan menutup pelajaran.

Sebagaimana yang diungkapkan oleh Murni Kabalmay, bahwa:

Bisanya kalau ngajar itu sebelum saya menjelaskan materi terlebih dahulu saya mengkondisikan mental dan menarik perhatian peserta didik pada materi yang akan dipelajari misalnya dengan menceritakan kejadian aktual atau yang relevan dengan isi dan indikator kompetensi yang akan dipelajari peserta didik. Setelah crita kemudian peserta didik saya beri pertanyaan yang terkait dengan crita yang saya berikan. Tapi yo...ceritanya tidak boleh lama-lama nanti peserta didik malah tidak jadi belajar. Pokoknya cerita sekedarnya saja supaya peserta didik tertarik untuk belajar. Biasanya dalam pembelajaran itu peserta didik susah membaca maka peserta didik diberi pertanyaan yang ada hubungannya dengan kompetensi yang akan dicapai yang materinya terdapat di dalam buku mata pelajaran dan LKS. Sedang pada akhir pelajaran saya 
mengemukakan kembali pokok-pokok pelajaran supaya peserta didik memperoleh gambaran utuh tentang pokok-pokok materi dan hasil belajar yang telah dipelajari. Istilahnya peserta didik diberi penguatan materi. ${ }^{16}$

Komponen keterampilan guru mengelola pembelajaran tidak terlepas usaha guru menciptakan suasana sikap mental dan menimbulkan perhatian peserta didik agar terarah pada hal-hal yang akan dipelajari. Dalam usaha menarik perhatian dan memotivasi peserta didik guru sebagaimana yang diungkapkan oleh Murni Kabalmay, S.Pd.I pada pernyataannya di atas yaitu dengan memberikan cerita terkait dengan materi yang akan di pelajari. Guru yang memiliki improvisasi metode pembelajaran yang relevan akan dapat menarik perhatian dan motivasi belajar peserta didik.

Berdasarkan pernyataan Murni Kabalmay, di atas bahwa pola interaksi yang dilakukan ketika menjelaskan pelajaran bukan interaksi monoton akan tetapi guru juga melibat aktifkan peserta didik. Hal tersebut juga dibenarkan oleh Sauda Waliulu, yaitu:

Biasanya kalau menjelaskan pelajaran itu saya bukan ceramah saja dari awal sampai akhir pelajaran dimana guru menerangkan-peserta didik mendengarkan atau guru bertanya peserta didik menjawab biasanya tidak bisa memikat perhatian peserta didik untuk waktu yang lama, akan tetapi saya menjelaskan materi kemudian menanyakan materi kepada peserta didik kemudian peserta didik langsung jawab atau biasanya peserta didik saya beri pertanyaaan atau permasalahan untuk dipecahkan kemudian peserta didik mengadakan diskusi kecil (power two) biasanya peserta didik lebih tertarik kalau saya suruh peserta didik memecahkan masalah dengan belajar berkelompok. Saya cuma mengawasi peserta didik belajar setelah itu ya...peserta didik saya suruh presentasi hasil kerjanya dan ditanggapi oleh peserta didik yang lain. ${ }^{17}$

\footnotetext{
${ }^{16}$ Murni Kabalmay, S.Pd.I, Kepala MA Al-Fatah Ambon, Wawancara tanggal 12 Desember 2018.

${ }^{17}$ Sauda Waliulu, S.Ag, M.Pd, Guru Pendidikan Agama Islam MA Al-Fatah Ambon, Wawancara tanggal 17 Desember 2018.
} 
Ketika guru menerangkan materi diperlukan keahlian dalam menciptakan suasana belajar peserta didik secara aktif yaitu dengan pola interaksi yang bervariasi dan pemilihan metode yang tepat yang menarik perhatian peserta didik. Sebagaimana yang dilakukan oleh Sauda Waliulu, bahwa untuk menerangkan pelajaran guru harus menyesuaikan dengan materi yang akan diajarkan. Berikut pernyataan Suciyana bahwa:

Kalau jadi guru itu ya...bukan cuma menggunakan satu metode saja dalam mengajar tapi bervariasi disesuaikan dengan materi yang akan diajarkan seperti halnya mata pelajaran yang saya ampu adalah PAI jadi pembelajaranya titik tekannya bukan saja pada penjelasan teori akan tetapi PAI itu praktek agama kaitannya dengan masalah-masalah ubudiyah seperti sholat, wudhu, puasa, zakat, kurban dsb. Sehingga dalam pembelajarannya saya langsung pada penerapan bukan sekedar pemberian teori. Seperti halnya materi haji dan umroh, peserta didik-peserta didik langsung saya suruh praktek. Karena bagi saya metode demonstrasi cukup efektif membuat peserta didik benar-benar paham pelajaran. ${ }^{18}$

Proses pembelajaran pada hakikatnya untuk mengembangkan aktivitas kreativitas peserta didik melalui berbagai interaksi dan pengalaman belajar. Apa yang dilakukan oleh guru pendidikan agama Islam di MA Al-Fatah Ambon memberikan gambaran kemampuan guru dalam mengelola pembelajaran dengan kemampuan mengelola pembelajaran dengan pola interaksi belajar dan metode pembelajaran yang bervariasi yang bertujuan untuk menciptakan pembelajaran efektif dan menyenangkan.

b) Kemampuan menggunakan alat peraga dan pemanfaatan teknologi pembelajaran

Abad 21 merupakan abad pengetahuan sekaligus merupakan abad informasi dan teknologi, karena canggihnya penggunaan pengetahuan, informasi dan teknologi dalam berbagai aspek kehidupan yang menimbulkan persaingan hidup yang sangat

${ }^{18}$ Suciyana, S.Pd.I, Guru Pendidikan Agama Islam MA Al-Fatah Ambon, Wawancara tanggal 17 Desember 2018. 
ketat siapa yang menguasai pengetahuan, teknologi dan informasi maka dialah yang akan menguasai hidup secara survival. Oleh karena itu, sudah sewajarnyalah guru dituntut untuk memiliki kompetensi dalam pemanfaatan teknologi pembelajaran terutama internet (elearning) agar guru mampu memanfaatkan berbagai pengetahuan, teknologi dan informasi dalam melaksanakan tugas utamanya mengajar dan membentuk kompetensi peserta didik.

Berkaitan dengan hal tersebut maka berdasarkan hasil wawancara penulis dengan guru pendidikan agama Islam di MA Al-Fatah Ambon mereka mengungkapkan bahwa dalam pembelajaran guru jarang sekali atau bahkan tidak pernah menggunakan fasilitas teknologi pembelajaran seperti halnya internet, komputer, video recorder, LCD proyektor dan sebagainya.

Sebagaimana yang diungkapkan oleh Murni Kabalmay, yaitu:

Kalau mengajar saya tidak pernah menggunakan media atau alat yang ada hubungannya dengan teknologi informasi karena bagi saya materi yang saya ajarkan itukan materi pendidikan agama Islam yang lebih menekankan pada pemahaman agama secara teoritis jadi tidak ada sangkut pautnya kalau saya menggunakan komputer, LCD atau apapun itu. ${ }^{19}$

Sebagai seorang tenaga pengajar hendaknya guru mampu secara inovatif mengembangkan pembelajarannya seiring dengan perkembangan ilmu pengetahuan dan teknologi. Berdasarkan hasil observasi di MA Al-Fatah Ambon peneliti melihat bahwa guru pendidikan Agama Islam belum secara maksimal memanfaatkan teknologi sebagai media pembelajaran. Padahal madrasah tersebut memberikan fasilitas yang mendukung seperti halnya Labolatorium Komputer, Perpustakaan dan multi media yang dilengkapi TV dan VCD player, kaset, video recorder dan LCD proyektor yang diharapkan mampu menunjang proses belajar mengajar. ${ }^{20}$ Akan tetapi hal ini tidak pernah dilakukan oleh guru pendidikan Islam khususnya guru mata pelajaran agama Islam.

\footnotetext{
${ }^{19}$ Murni Kabalmay, S.Pd.I, Kepala MA Al-Fatah Ambon, Wawancara tanggal 12 Desember 2018.

${ }^{20}$ Hasil Observasi di MA Al-Fatah Ambon pada tanggal 17 Desember 2018.
} 
Sebagaimana yang diungkapkan oleh Bakri yaitu:

Walaupun madrasah ini memberikan fasilitas media pembelajaran yang mendukung saya...kurang tertarik kalau saya mengajar dengan menyetelkan film-film atau kisah-kisah yag ada kaitannya dengan sejarah

Islam. Karena bagi saya terlalu memakan banyak waktu sehingga efesiensi waktu yang saya pertimbangkan apalagi listrik juga sering padam di pagi hari dengan alasan ganggung jaringan kabel listrik dan lin-lain yang dikhawatirkan media yang ada menjadi rusak. Jadi pembelajaran ya...cukup saya terangkan saja di kelas. ${ }^{21}$

Berdasarkan urian yang dikemukakan di atas, maka dapat dikatakan bahwa walaupun fasilitas pendidikan bukan salah satunya faktor yang mendukung keberhasilan dan kualitas pendidikan di madrasah akan tetapi kemajuan teknologi informasi menuntut bagi para guru untuk inovatif dalam pembelajarannya sesuai dengan perkembangan IPTEK sehingga metode dan model pembelajaran bukan lagi menggunakan model pembelajaran tradisional di mana guru menerangkan dan peserta didik mendengarkan akan tetapi model pembelajaran yang menuntut keaktifan peserta didik dengan pemanfaatan teknologi e-learing dalam pembelajaran. 3) Kemampuan melaksanakan penilaian proses belajar mengajar

Menguji merupakan bagian terpenting dalam pembelajaran, yang dilakukan oleh seorang guru untuk mengetahui tingkat pengetahuan awal, kecakapan peserta didik dan program pengajaran. Oleh karena itu sebagai guru dituntut untuk lihai dalam melakukan evaluasi pembelajaran. Model evaluasi yang dilakuan oleh Guru Pendidikan Agama Islam di MA Al-Fatah Ambon sebagaimana yang dilakukan oleh Suciana, bahwa:

Bentuk penilaian yang biasanya dilakukan yang pertama yaitu melihat sikap peserta didik melalui proses belajar mengajar, bagaimana sikap peserta didik pada mata pelajaran PAI apakah peserta didik itu senang atau tidak. Dalam hal ini dapat diketahui melalui penugasan yang biasanya dilakukan ketika guru

${ }^{21}$ Bakri, S.Pd.I, M.Pd, Guru Pendidikan Agama Islam MA Al-Fatah Ambon, Wawancara tanggal 12 Desember 2018. 
melakukan pembelajaran. Dalam proses pembelajaran menerapkan penilaian melalui 3 cara yaitu: Pertama melalui portopolio yaitu peserta didik saya suruh mengejakan tugas yang terdapat dalam LKS dan dalam pengerjaan LKS guru tidak membatasi waktu dan halamannya, semakin cepat dan banyak peserta didik mengerjakan soal LKS maka semakin banyak nilai yang peserta didik tersebut dapatkan. Jadi dalam hal ini yang dinilai adalah gairah peserta didik dalam belajar kalau peserta didik semangat mengerjakan tugas berarti peserta didik tersebut antusias belajar. Makanya guru memberi penghargaan dengan nilai bagi peserta didik yang mempunyai antusias tinggi dalam mengerjakan tugas. Kedua adalah melalui tugas Pekerjaan Rumah yang mana soalsoalnya diambil dari materi-materi yang sudah dijelaskan sebelumnya. Ketiga melalui tes, baik itu tes wawancara atau tanya jawab langsung setelah mata pelajaran selesai atau tes tertulis yang dilaksanakan setiap habis bab melalui soal yang berbentuk pilihan ganda dan uraian, dan diakhiri dengan ulangan akhir bersama pada akhir semester. ${ }^{22}$

Berkenaan dengan ungkapan terssebut, maka sebgaimana yang diungkapkan juga oleh guru PAl yang lain yakni Bakri sebagai guru mata pelajaran PAI adalah bentuk penilaian berbasis kelas yaitu penilaian yang dilakukan dalam bentuk pertanyaan lisan di kelas, ulangan harian, tugas kelompok, ulangan semester, ulangan kenaikan kelas, sebagaimana berikut:

1) Pertanyaan lisan dikelas: yaitu sebelum memulai pembelajaran terlebih dahulu guru memberikan pertanyaan lisan kepada peserta didik berupa pemahaman terhadap materi yang telah dijelaskan. Pertanyaan ini guru lemparkan kepada peserta didik kemudian diberikan kesempatan mereka untuk berfikir, kemudian guru memilih secara acak peserta didik untuk menjawab pertanyaan tadi. Jawaban tersebut diberi kebebasan mereka mengeluarkan gagasannya, benar atau salah jawaban yang didapat dari peserta didik, selanjutnya guru melempar lagi kepada peserta didik untuk mendapat klarifikasi jawaban yang

${ }^{22}$ Suciyana, S.Pd.I, Guru Pendidikan Agama Islam MA Al-Fatah Ambon, Wawancara tanggal 17 Desember 2018. 
pertama. Setelah itu guru dapat menyimpulkan tentang jawaban peserta didik yang benar. Pertanyaan ini dapat dilakukan pada awal dan akhir pelajaran.

2) Ulangan harian yang biasanya dilakukan secara periodik, misalnya etiap selesai 1 atau 2 bab.

3) Tugas kelompok digunakan untuk menilai kemampuan kerja kelompok. Biasanya peserta didik ditugasi untuk memecahkan permasalahan yang terkait dengan materi secara berkelompok, dan

4) Ulangan semester yaitu ulangan yang biasanya dilakuan pada akhir semester dengan bentuk solah ujian pilihan ganda atau uraian, sedang untuk materi yang diujikan berdasarkan ada kisi-kisi soal untuk melihat pemahaman peserta didik terhadap materi selama satu semester. ${ }^{23}$

Sedangkan bentuk evaluasi yang dilakukan oleh Sauda Waliulu, sebagai guru PAl lebih menekankan bahwa:

Pemahaman peserta didik terhadap materi yang telah diajarkan seperti halnya peserta didik dianjurkan mencari data lapangan atau melakukan pengamatan terhadap sesuatu fenomena misalnya peserta didik disuruh mencari data di majalah, koran, internet, televisi maupun radio terkait dengan contoh akhlak terpuji dan akhlak tercela kemudian peserta didik diperintahkan untuk menceritakan kembali hasil data yang telah diperoleh untuk dilakukan refleksi di mana peserta didik diperintahkan untuk meragkum atau mengambil hikmah untuk kemudian dikaitkan dengan kehidupan sehari-hari. Penilaian atau evaluasi yang dilakukan bukan saja berpaku pada ranah kognitif terkait dengan materi pelajaran yang biasa dilakukan setiap selesai satu pokok bahasan dan pada akhir semester tetapi juga ditekakan pada penilaiaan afektif (sikap peserta didik) dan psikomotor. ${ }^{24}$

${ }^{23}$ Bakri, S.Pd.I, M.Pd, Guru Pendidikan Agama Islam MA Al-Fatah Ambon, Wawancara tanggal 12 Desember 2018.

${ }^{24}$ Sauda Waliulu, S.Ag, M.Pd, Guru Pendidikan Agama Islam MA Al-Fatah Ambon, Wawancara tanggal 17 Desember 2018. 
Berkenaan dengan penuturan yang disampaikan oleh informan di atas, maka disampaikan juga melalui Suciana yang mengungkapkan bahwa:

Setelah mengetahui hasil dari evaluasi maka langkah selanjutnya yang dilakukan adalah tindak lanjut bagi peserta didik yang nilainya mencapai standar kompetensi maka diberikan program pengayaan materi sedang peserta didik yang nilai belajarnya kurang diberikan program remidial yaitu dengan mengulang kembali materi yang telah diajarkan sampai peserta didik benar-benar paham kemudian diadakan tes lisan. ${ }^{25}$

Dari pemaparan dari para informan di atas, sebagaimana hasil observasi yang peneliti lakukan, dimana peneliti melihat bahwa penilaian yang dilakukan oleh guru pendidikan Agama Islam menunjukkan bahwa guru pendidikan agama Islam di MA Al-Fatah Ambon mampu melakukan penilaan atau evaluasi, yang dilakukan baik itu evaluasi berbentuk tes formatif yaitu setiap guru selesai menyelesaikan satu pokok bahasan atau setiap selesai menjelaskan materi dan evaluasi pada akhir semester. Selain dari pada itu, guru pendidikan Agama Islam juga melakukan program pengayaan dan remidial. ${ }^{26}$

Berdasarkan hasil penuturan informan dan hasil observasi, maka dapat dikatakan bahwa evaluasi yang dilakukan ghuru PAI di MA Al-Fatah Ambon sudah dilakukan dan sangat berguna untuk melihat perubahan kecakapan dalam tingkat pengetahuan peserta didik sehingga pengetahuan dan keterampilan serta perubahan sikap dalam satu unit pembelajaran atau dalam program pembelajaran yang telah dilakukan dapat tercapai dengan baik.

\section{b. Kompetensi Kepribadian}

Setiap guru dituntut untuk memiliki kompetensi kepribadian yang memadai. Dalam hal ini, guru tidak hanya dituntut untuk mampu memaknai pembelajaran tetapi yang paling penting adalah bagaimana menjadikan pembelajaran sebagai ajang pembentukan pribadinya. Untuk kepentingan tersebut dalam bagian ini dibahas

${ }^{25}$ Suciyana, S.Pd.I, Guru Pendidikan Agama Islam MA Al-Fatah Ambon, Wawancara tanggal 17 Desember 2018.

${ }^{26}$ Hasil Observasi di MA Al-Fatah Ambon pada tanggal 12 Desember 2018. 
tentang gambaran kompetensi kepribadian guru pendidikan Agama Islam di MA AlFatah Ambon yang berkaitan dengan kompetensi kepribadian yang mantap, stabil, dewasa, disiplin, arif dan berwibawa serta berakhlak mulia.

1) Disiplin

Sehubungan dengan kompetensi kepribadian yang dimiliki oleh guru pendidikan agama Islam di MA Al-Fatah Ambon adalah usaha dari para guru dalam membimbing dan mengarahkan perilaku peserta didik ke arah yang positif dan menunjang pembelajaran. Sebagai contoh guru selalu memperlihatkan perilaku disiplin yang baik dengan datang ke madrasah tepat waktu, apabila waktunya bel masuk kelas guru langsung bersegera datang ke kelas sebelum para peserta didiknya datang, karena bagaimana peserta didik akan disiplin kalau gurunya tidak menunjukkan siap disiplin (self-discipline). Sikap disiplin dari para guru diharapkan menjadi teladan bagi peserta didik untuk meniru perilaku disiplin guru yang baik.

Pola kedisiplinan para guru pendidikan agama Islam tidak terlepas dari peran serta kepala madrasah Sudirman dimana dalam kepemimpinanya beliau sangat aktif mendisiplinkan guru-guru. Sebagaimana yang diungkapkan oleh Bakri bahwa:

Kedisiplinan dari para guru di madrasah ini tidak terlepas dari peran serta kepala madrasah dalam mendisiplinkan guru. Beliau sangat aktif dan selalu mendorong para guru agar senantiasa disiplin tetapi kepala madrasah juga memberi contoh tiap kali masuk pagi beliau selalu datang lebih awal, keliling ke tiap kelas untuk mengecek guru yang belum masuk, apabila ada guru yang belum datang langsung ditelpon. Selain daripada itu kepala madrasah memberlakukan peraturan bagi seluruh guru untuk bertanggungjawab pada tugas mengajarnya. Apabila berhalangan hadir harus izin langsung kepada kepala madrasah dan memberikan tugas kepada peserta didiknya. Dan Alhamdulillah semua guru disini jarang sekali izin kecuali ada keperluan yang mendesak sehingga tidak pernah ada kelas yang kosong. ${ }^{27}$

${ }^{27}$ Bakri, S.Pd.I, M.Pd, Guru Pendidikan Agama Islam MA Al-Fatah Ambon, Wawancara tanggal 12 Desember 2018. 
Berdasarkan hasil observasi penulis di lapangan bahwa di MA Al-Fatah Ambon guru PAI dan guru lainnya senantiasa menanamkan pola kedispilinan yang didukung oleh seluruh komponen madrasah. Seperti contohnya madrasah ini mengadakan kegiatan wajib yang diikuti oleh seluruh komponen madrasah yaitu upacara bendera, tadarus Al-Qur'an pada hari Jumat pagi, sehingga hal ini mengharuskan bagi para guru untuk senantiasa datang tepat waktu ke madrasah. Pembiasaan seperti inilah yang membentuk kepribadian dari para guru di MA Al-Fatah Ambon untuk senantiasa disiplin dalam segala hal, baik itu yang berkaitan dengan ketepatan waktu atau disiplin dalam melaksanakan tugas mengajar. ${ }^{28}$

Sebagaimana yang telah penulis sebutkan di atas, makan dapat disimpulkan bahwa guru-guru di MA Al-Fatah Ambon berupaya untuk menjadi teladan yang baik bagi para peserta didiknya terbukti dari pola kedispilinan para guru saat masuk kelas, apabila sudah waktunya bel berbunyi guru yang bertugas mengajar memberi contoh dengan bersegera datang ke kelas sebelum peserta didik-siswinya masuk kelas, ketika guru mendapati peserta didik yang bolos atau terlambat maka guru tersebut langsung melakukan tindak lanjut yaitu dengan melaporkan pada petugas TATIB (tata tertib) madrasah yang bertugas pada hari tersebut atau melakukan konfirmasi kepada orang tua peserta didik terkait dengan ketidak-hadiran peserta didik di madrasah. Melalui berbagai upaya tersebut diharapkan tercipta iklim yang kondusif bagi pembelajaran yang didukung oleh seluruh komponen madrasah.

2) Berakhlak mulia, arif, dan berwibawa

Kedisiplinan yang dilakukan oleh guru pendidikan agama Islam di MA AlFatah Ambon memberikan indikasi yang kuat bahwa guru di madrasah ini mencoba memberikan teladan kepada seluruh peserta didiknya lewat sikap, perilaku, serta tutur kata yang baik. Sikap guru yang demikian mencerminkan akhlak yang mulia yang mencerminkan kepribadian seorang pendidik yang patut digugu dan ditiru. Digugu maksudnya bahwa pesan-pesan yang disampaikan guru bisa dipercaya untuk dilaksanakan dan pola hidupnya ditiru dan diteladani.

\footnotetext{
${ }^{28}$ Hasil Observasi di MA Al-Fatah Ambon pada tanggal 12 Desember 2018.
} 
Sehubungan dengan hal demikian maka sikap guru hendaklah terbuka menerima kritik, perbedaan pendapat serta adil dan tidak diskriminatif. Sebagaimana yang diungkapkan oleh Sauda Waliulu, terkait dengan sikap guru ketika menghadapi kritik atau perbedaan pendapat beliau mengatakan bahwa:

Saya bersikap terbuka kepada siapapun yang mengkritik saya baik itu dari peserta didik maupun dari rekan kerja asalkan disampaikan dengan cara yang baik. Sedang kalau perbedaan pendapat itu wajar terjadi dalam setiap pergaulan manusia sehingga kalau saya menghadapi perbedaan pendapat ya...legowo, menerima, bersikap netral dan mencoba untuk menjadi pendengar yang baik bagi orang lain. Demikian juga ketika saya menghadapi peserta didik-peserta didik saya berusaha bersikap adil tidak membedabedakan dalam perlakuan dalam maupun penilaiaan semua saya perlakukan sama secara proporsional. ${ }^{29}$

Pernyataan di atas menggambarkan figur seorang guru senantiasa berusaha untuk menjadi suri tauladan yang sehingga guru tidak hanya mentransferkan ilmu pengetahuan kepada peserta didiknya. Guru juga menjadi pelopor untuk menciptakan orang-orang yang berbudaya, berbudi dan bermoral lewat sikap empati, terbuka, berwibawa, bertanggung jawab yang merupakan kemampuan berpikir yang diikuti dengan tindakan secara simultan yang memadai dalam situasi tertentu.

Berdasarkan hasil observasi yang peneliti lakukan, dimana peneliti melihat bahwa guru PAI di MA Al-Fatah Ambon senantiasa disiplin datang tepat waktu ke madrasah ketika mendapatkan peserta didik yang bolos atau terlambat maka dengan segera guru melakukan tindak lanjut dengan memberikan melaporkan kepada pihak keamanan (TATIB) madrasah yang bertugas atau konfirmasi kepada orang tua peserta didik kemudian mengadakan pendekatan secara individual kepada peserta didik untuk memecahkan permasalahan yang terjadi pada diri peserta didik. ${ }^{30}$

Berdasarkan penjelasan yang telah dipaparkan di atas, maka dapat disimpulkan bahwa gambaran tentang kompetensi psikologis guru di MA Al-Fatah

\footnotetext{
${ }^{29}$ Sauda Waliulu, S.Ag, M.Pd, Guru Pendidikan Agama Islam MA Al-Fatah Ambon, Wawancara tanggal 17 Desember 2018.

${ }^{30}$ Hasil Observasi di MA Al-Fatah Ambon pada tanggal 12 Desember 2018.
} 
Ambon yang senantiasa menanamkan kedisiplinan, memberian contoh teladan yang baik, terbuka terhadap kritik maupun perbedaan pendapat, tidak diskriminatif serta luwes dalam bertindak.

\section{c. Kompetensi Sosial}

1) Berkemampuan untuk berkomunikasi dengan peserta didik

Dilihat dari peran guru di kelas, mereka berperan sebagai seorang komunikator yang mengkomunikasikan materi dalam bentuk verbal maupun nonverbal. Pesan yang akan dikomunikasikan hendaknya dikemas sedemikian rupa sehingga mudah dipahami, dimengerti, dipelajari, dicerna dan diaplikasikan para peserta didik. Oleh karena itu, menuntut kemampuan dan kelihaian guru dalam berkomunikasi dengan peserta didik. Komunikasi antara guru dan peserta didik tidak terbatas di dalam kelas semata tetapi juga di luar kelas.

Sehubungan dengan hal tersebut sebagaimana observasi yang peneliti temukan bahwa guru pendidikan agama Islam dalam hal komunikasi dengan peserta didik masih terbatas pada hubungan guru dengan peserta didik yaitu komunikasi pembelajaran yang hanya dilakukan di kelas saja sedang untuk komunikasi secara interpersonal masih belum dilaksanakan secara intensif. Bentuk komunikasi peserta didik dengan guru di luar kelas yaitu apabila ada peserta didik yang mengalami kesulitan memahami materi maka guru terbuka apabila peserta didik membutuhkan pendalaman materi secara khusus. ${ }^{31}$

2) Berkemampuan komunikasi dengan kepala madrasah

Berdasarkan observasi yang peneliti lakukan ketika melakukan penelitian, dimana peneliti dilihat bahwa bentuk komunikasi guru di MA Al-Fatah Ambon dengan kepala madrasah adalah bentuk komunikasi instruksional yaitu hubungan kerja antara atasan dengan bawahan terkait dengan kebijakan, perencanaan program madrasah, evaluasi serta pengembangan kualitas dan kuantitas pembelajaran. ${ }^{32}$

Dari hasil observasi tersebut dimana peneliti melihat bahwa kepala madrasah MA Al-Fatah Ambon sangat aktif dalam menertibkan para guru, hal ini tidak terlepas dari kemampuan komunikasi yang baik dari kedua belah pihak yaitu pihak kepala

\footnotetext{
${ }^{31}$ Hasil Observasi di MA Al-Fatah Ambon pada tanggal 12 Desember 2018.

${ }^{32}$ Hasil Observasi di MA Al-Fatah Ambon pada tanggal 12 Desember 2018.
} 
madrasah dan pihak guru. Hal ini sebagaiman diungkapakan oleh Sauda Waliulu, bahwa:

Bentuk kerjasama antara guru dengan kepala madrasah adalah kepala madrasah mengadakan program pertemuan seluruh guru dan pegawai yang diadakan seminggu sekali setiap hari Rabu setelah jam pelajaran madrasah usai, di mana pada rapat tersebut dibahas mengenai berbagai hal yang berkaitan dengan permasalahan madrasah baik yang meliputi evaluasi, perencanaan program madrasah serta peningkatan kualitas pembelajaran yaitu dengan meningkatkan kualitas kompetensi guru melalui pelatihan pembuatan silabi, pelatihan pembuatan rencana pembelajaran, pelatihan pelaksanaan Penelitian Tindakan Kelas (PTK), serta Musyawarah Guru Mata Pelajaran (MGMP) dan sebagainya. ${ }^{33}$

Selain yang sampaikan oleh Informan tersebut, selanjutnya Murni Kabalmay, mengungkapkan bahwa:

Saya selaku kepala madrasah berperan memengawasi setiap kinerja dari masing-masing guru dan pegawai, memotivasi keaktifan guru serta mengadakan evaluasi kerja yaitu dalam rapat yang diadakan setiap satu bulan sekali di mana pada rapat tersebut diadakan sharing (tukar pendapat) mengenai permasalahan yang dihadapi oleh guru-guru untuk kemudian dipecahkan bersama solusinya. ${ }^{34}$

Berdasarkan penuturan dari informan tersebut, maka dapat disimpulkan bahwa komunikasi yang dilakukan oleh guru di MA Al-Fatah Ambon khususnya guru pendidikan Agama Islam adalah komunikasi secara instruksional terkait dengan hubungan kerja dan tugas antara atasan dengan bawahan. Kemampuan yang dimiliki oleh guru pendidikan agama Islam di MA Al-Fatah Ambon dalam

\footnotetext{
${ }^{33}$ Sauda Waliulu, M.Pd, Guru Pendidikan Agama Islam MA Al-Fatah Ambon, Wawancara tanggal 17 Desember 2018.

${ }^{34}$ Murni Kabalmay, S.Pd.I, Kepala MA Al-Fatah Ambon, Wawancara tanggal 12 Desember 2018.
} 
berkomunikasi tergambar melalui kemampuan guru dalam menyampaikan gagasan, ide atau pendapat berkaitan dengan pengembangan program madrasah.

3) Kemampuan berkomunikasi dengan teman sesama guru

Berkaitan dengan hal yang tersebut di atas, maka gambaran hubungan dengan sesama guru di MA Al-Fatah Ambon adalah guru-guru di madrasah ini berusaha menciptakan hubungan harmonis baik hubungan yang berkaitan dengan tugas kedinasan maupun hubungan kekeluargaan. Sebagaimana yang diungkapkan oleh Bakri bahwa:

Kalau bicara mengenai hubungan sesama guru maka kami selaku guru-guru di madrasah ini berusaha menciptakan hubungan yang baik dengan teman sejawat baik itu hubungan yang berkaitan dengan hubungan kekeluargaan maupun yang berkaitan dengan tugas kedinasan seperti kegiatan mengajar. Sebagai contohnya saya sebagai guru sering sharing (berbagi) dengan teman-teman kalau ada materi-materi atau istilah-istilah yang tidak saya ketahui atau dalam musyawarah guru mata pelajaran (MGMP) atau dalam kegiatan kelompok kerja guru (KKG) atau kadang saya meminta pendapat sama guru lain ketika saya mengalami kesulitan dalam mengelola pembelajaran. $^{35}$

Berdasarkan penjelasan di atas maka dapat disimpulkan bahwa kegiatan tersebut menggambarkan kemampuan guru pendidikan agama Islam di MA Al-Fatah Ambon dalam berkomunikasi dengan teman sejawat (teman sesama guru) yaitu komunikasi yang harmonis, kekeluargaan dan dialogis. Kegiatan semacam ini menuntut kepada seluruh guru untuk terlibat aktif dan mampu berkomunikasi yang baik dengan sesama, luwes dalam bergaul, memiliki keterbukaan berfikir, kemampuan bersosialisasi dengan orang lain.

4) Kemampuan berkomunikasi dengan orang tua peserta didik

Peranan guru di madrasah bukan saja terbatas untuk memberikan pembelajaran tetapi harus memikul tanggungjawab terhadap keberhasilan peserta

${ }^{35}$ Bakri, S.Pd.I, M.Pd, Guru Pendidikan Agama Islam MA Al-Fatah Ambon, Wawancara tanggal 12 Desember 2018. 
didik yang telah diajarnya utamanya tanggungjawab guru kepada orang tua peserta didik.

Berikut ini hasil wawancara peneliti dengan beberapa guru pendidikan agama Islam terkait dengan sikap guru mengenai komunikasi dengan orang tua peserta didik:

Murni Kabalmay, menuturkan bahwa Kalau komunikasi dengan orang tua peserta didik saya jarang sekali atau bahkan tidak pernah kecuali kalau saya sebagai wali kelas mungkin bisa berkomunikasi langsung dengan orang tua peserta didik apabila peserta didik mengalami permasalahan di madrasah tetapi saya tidak pernah berkomunikasi langsung dengan orang tua peserta didik. $^{36}$

Selain itu, Sauda Waliulu menuturkan bahwa: Bentuk komunikasi saya dengan orang tua peserta didik itu hanya kalau peserta didik mengalami permasalahan terkait dengan sikap peserta didik di madrasah, kalau ada peserta didik yang sering bolos, kurang perhatian dengan pelajaran atau malas belajar, atau peserta didik nakal. biasanya saya langsung panggil orang tuanya dengan tujuan untuk sharing dengan orang tua peserta didik sehingga permasalahan peserta didik di madrasah dapat ditemukan solusinya. ${ }^{37}$

Selanjutnya Bakri menuturkan bahwa: Biasanya kalau ada peserta didik bolos atau tengah-tengah pelajaran saya konfirmasi dengan oarang tua peserta didik, terutama pada waktu rapotan kita sharing dengan orang tua peserta didik. $^{38}$

Sementara Suciana menuturkan bahwa: Saya tidak pernah berhubungan langsung dengan orag tua peserta didik tetapi bentuk pendekatan saya

\footnotetext{
${ }^{36}$ Murni Kabalmay, S.Pd.I, Kepala MA Al-Fatah Ambon, Wawancara tanggal 12 Desember 2018.

${ }^{37}$ Sauda Waliulu, S.Ag, M.Pd, Guru Pendidikan Agama Islam MA Al-Fatah Ambon, Wawancara tanggal 17 Desember 2018.

${ }^{38}$ Bakri, S.Pd.I, M.Pd, Guru Pendidikan Agama Islam MA Al-Fatah Ambon, Wawancara tanggal 12 Desember 2018.
} 
mungkin cukup dengan peserta didik saja. Sebagai guru sedikit banyak saya mencari tahu tentang latar belakang peserta didik agar saya dapat memberikan treatment (perlakuan) tersendiri setelah saya tahu latar belakang peserta didik. Misalnya menghadapi peserta didik yang nakal karena latar belakang keluarganya broken home maka saya berusaha untuk mendekati secara personal akan tetapi saya pribadi tidak pernah berhubungan langsung dengan orang tua peserta didik mungkin karena keterbatasan waktu dan alat komunikasi maka komunikasi saya cukup dengan peserta didik. Kalau saya mampu memberikan pesan dan kesan yang baik kepada peserta didik maka secara tidak langsung saya juga sudah berkomunikasi dengan baik dengan orang tua peserta didik. ${ }^{39}$

Berdasarkan jawaban dari sikap guru-guru pendidikan agama Islam di atas, tergambar bahwa kemampuan komunikasi guru dengan peserta didik hanya terbatas pada komunikasi yang dilakukan apabila peserta didik mengalami permasalahan atau penyimpangan di madrasah sedang untuk komunikasi terkait dengan hubungan personal antara guru dan orang tua peserta didik jarang sekali atau bahkan tidak pernah dilakukan kecuali apabila guru bertindak sebagai wali kelas dan itupun hanya sebatas pada waktu peserta didik rapotan.

5) Kemampuan berinteraksi dengan masyarakat

Sebagaimana telah dikemukakan di atas bahwa kompetensi sosial adalah kemampuan guru sebagai bagian dari masyarakat untuk bergaul secara efektif dengan peserta didik, sesama pendidik, tenaga kependidikan, orang tua atau wali dan masyarakat sekitar.

Berdasarkan uraian hasil wawancara penulis dengan guru pendidikan agama Islam di MA Al-Fatah Ambon di atas, maka dapat penulis simpulkan bahwa sebagian besar guru di madrasah ini terlibat aktif dalam kegiatan sosial kemasyarakatan baik itu yang berkaitan dengan kegiatan keagamaan maupun kegiatan kepemudaan seperti halnya peran serta dalam kegiatan KKN/PPL mahasiswa dan sebagainya.

${ }^{39}$ Suciyana, S.Pd.I, Guru Pendidikan Agama Islam MA Al-Fatah Ambon, Wawancara tanggal 17 Desember 2018. 


\section{d. Kompetensi Profesional}

1) Kemampuan menguasai bidang studi yang diajarkan

Guru dituntut memiliki keahlian profesi dalam hal penguasaan materi pengetahuan yang terukur dan teruji sesuai fungsi perannya, mengajar dan mengembangkan bahan ajar, serta mengaplikasikan ilmu pengetahuan dalam dinamika kehidupan yang nyata.

Hal ini sebagaimana diungkapkan oleh Murni Kabalmay bahwa:

Semua guru yang mengajar di MA Al-Fatah Ambon sudah memenuhi standar kualifikasi sebagai guru berdasarkan bidang keahlian masing-masing sehinga tugas keprofesionalan guru di madrasah kami ini memang sudah tetap dan bila maih ada lagi penambahan kami meminta guru TIK (teknik informasi dan komunikasi) karena guru mata pelajaran yang lain sudah terisi semuanya dan sudah berkaulifikasi starata satu (S1) dan bahkan ada yang berkualifikasi starata $2(\mathrm{~S} 2)^{40}$

Berdasarkan Keputusan Mentri Pendidikan Nasional Republik Indonesia Nomor 034/U/2003, pasal 8 butir $\mathbf{d}$ yang berbunyi sebagai berikut: untuk guru SMAsederajat adalah lulusan $\mathrm{S} 1$ Kependidikan atau $\mathrm{S} 1$ non-Kependidikan yang mempunyai Akta IV dan apabila sangat diperlukan dapat diterima lulusan D III Kependidikan atau D III non-Kependidikan yang mempunyai Akta III, atau D II/Akta II mata pelajaran atau sederajat. ${ }^{41}$

Berdasarkan uraian pemaparan yang telah dikemukakan di atas, maka dapat disimpulkan bahwa ketrampilan dalam pekerjaan profesi sangat didukung oleh teori yang telah dipelajarinya. Jadi seorang profesional dituntut membaca dan mendalami teori tentang profesi yang digelutinya. Penerapan lapangan tidak akan mencapai hasil maksimal apabila dilakukan dengan meraba-raba dan mencoba-coba akan tetapi suatu penerapan harus memiliki pedoman teoritis.

2) Kemampuan memahami peserta didik

\footnotetext{
${ }^{40}$ Murni Kabalmay, S.Pd.I, Kepala MA Al-Fatah Ambon, Wawancara tanggal 12 Desember 2018

${ }^{41}$ Undang-Undang SISDIKNAS UU RI No.20 Th.2003 pasal 8 butir d, hlm. 82.
} 
Pemahaman terhadap peserta didik membutuhkan kejelian dan keaktifan dari guru, oleh karena itu sebagai seorang tenaga pengajar guru hendaknya aktif memahami peserta didik. Adapun gambaran mengenai kemampuan yang dilakukan guru agama dalam memahami peserta didik sebagaimana yang telah diungkapkan oleh Sauda Waliulu, selaku guru agama adalah:

Guru itu ibaratnya seorang dokter yang bertanggung jawab terhadap masalahmasalah serta keluhan yang dialami peserta didik untuk kemudian dicarikan solusi pemecahannya sehingga guru juga merupakan fasilitator peserta didik dalam pembelajaran. ${ }^{42}$

Berkaitan dengan ini, maka seorang guru hendaklah memahami betul kondisi peserta didiknya yang beragam baik itu yang berkaitan dengan tingkat kecerdasan peserta didik, bakat peserta didik, latar belakang peserta didik maupun yang berkaitan dengan prestasi atau hasil belajar peserta didik. Hal ini sebagaimana diungkpkan oleh Suciana bahwa:

kalau guru sudah memahami peserta didiknya dengan benar maka akan mempermudah guru dalam mendiagnosis kesulitan belajar peserta didik. Hal yang biasanya saya lakukan untuk memahami peseta didik yang pertama adalah melalui pendekatan individu, kedua pengamatan saya terhadap tingkah laku peserta didik di madrasah, dan yang ketiga adalah melalui hasil belajar peserta didik. Setelah saya mengetahui kondisi peserta didik maka langkah selanjutnya yang saya lakukan adalah mengklasifikasikan peserta didik menjadi tiga kelompok dengan perlakuan yang berbeda yang pertama kelompok peserta didik yang memiliki kemampuan atau intelektual tinggi maka dalam pembelajarannya saya banyak lakukan pengayaan atau tambahan materi, kelompok peserta didik yang memiliki kemampuan sedang saya

${ }^{42}$ Sauda Waliulu, S.Ag. M.Pd, Guru Pendidikan Agama Islam MA Al-Fatah Ambon, Wawancara tanggal 17 Desember 2018. 
lakukan pendalaman materi sedang bagi peserta didik yang memiliki kemampuan rendah saya lakukan remidi atau pengulangan. ${ }^{43}$

Pernyataan tersebut di atas, menggambarkan bahwa ada beberapa hal yang harus guru perhatikan dalam proses belajar mengajar yaitu pemahaman guru terhadap peserta didik yang nantinya akan membantu peserta didik mengatasi masalah-masalah pribadi dan sosial, mengatur disiplin kelas dengan baik, menilai hasil belajar dan kemajuan belajar peserta didik, melayani perbedaan-perbedaan individual peserta didik serta memberikan bimbingan bagi peserta didik sebagaimana yang diungkapkan oleh Bakri bahwa:

Kalau usaha yang saya lakukan untuk memahami peserta didik yaitu melalui bimbingan artinya sebagai guru saya berusaha memberikan layanan bimbingan utamanya adalah bimbingan kepada peserta didik dalam belajar agar peserta didik tidak mengalami kesulitan belajar. Sebagai contohnya saya melakukan pendekatan individu sehingga peserta didik bisa terbuka karena bagi saya peserta didik itu seperti teman saya sehingga tidak ada batasan antara guru dengan peserta didik. ${ }^{44}$

Sebagaimana yang telah dipaparkan di atas tentang pemahaman guru pendidikan agama Islam di MA AI-Fatah Ambon terhadap peserta didik yaitu dengan memberikan pelayanan terhadap perbedaan individual peserta didik, hal ini akan bermakna mpeserta didikala mendapat pelayanan yang optimal dari tenaga pendidik dan peserta didik mendapat kesempatan mengembangkan diri sesuai dengan kemampuan yang mereka miliki.

Dengan demikian, maka dapat disimpulkan bahwa guru mengenal peserta didik dengan maksud agar guru membantu pertumbuhan dan perkembangannya secara efektif. Adalah penting sekali mengenal dan memahami peserta didik dengan seksama, agar guru dapat menentukan dengan seksama bahan-bahan yang akan

\footnotetext{
${ }^{43}$ Suciyana, S.Pd.I, Guru Pendidikan Agama Islam MA Al-Fatah Ambon, Wawancara tanggal 17 Desember 2018.

${ }^{44}$ Bakri, S.Pd.I, M.Pd, Guru Pendidikan Agama Islam MA Al-Fatah Ambon, Wawancara tanggal 12 Desember 2018.
} 
diberikan, menggunakan prosedur mengajar yang serasi serta mengadakan diagnosis atas kesulitan belajar peserta didik.

3) Kemampuan menguasai pembelajaran yang mendidik

a. Memahami jenis materi pelajaran

Seorang guru harus memahami jenis-jenis materi pembelajaran. Beberapa hal penting yang harus dimiliki guru adalah kemampuan menjabarkan materi standar dalam kurikulum. Untuk kepentingan tersebut, guru harus mampu menentukan secara tepat materi yang relevan dengan kebutuhan dan kemampuan peserta didik. Sehubungan dengan hal tersebut berdasarkan hasil wawancara penulis dengan guru pendidikan agama Islam terkait dengan pertimbangan dalam memilih dan menentukan materi yang terkandung dalam silabus, kurikulum dan rencana pembelajaran, sebagaimana yang diungkapkan oleh Sauda Waliulu, bahwa:

Adapun pertimbangan saya dalam memilih dan menentukan materi yang pertama, materi itu harus tepat dalam artian bahwa ketika guru menerangkan harus menghindarkan pemberian dalil atau teori yang sebenarnya masih diperdebatkan. Kedua, keberartian artinya materi yang akan kita ajarkan sesuai dengan kebutuhan dan kemampuan peserta didik. Ketiga, relevansi artinya sesuai dengan tingkat kemampuan peserta didik, materi tidak terlalu susah dan juga tidak terlalu mudah. Keempat, kemenarikan artinya menarik perhatian peserta didik, mampu memotivasi peserta didik untuk belajar lebih lanjut. Kelima, kepuasan artinya materi yang kita ajarkan bermanfaat bagi kehidupannya. Sehingga ketika pembelajaran tidak mencapai target yang diinginkan maka sebagai guru hendaknya saya melakukan tindak lanjut dengan menambah pendalaman materi. ${ }^{45}$

Pertimbangan dalam memilih dan menentukan materi sebagaimana yang tersebut di atas tidak terlepas dari pemahaman guru terhadap jenis materi pembelajaran. Dalam setiap pengembangan materi pembelajaran guru hendaknya memperhatikan materi yang diajarkan sesuai dan cocok dengan tujuan dan

\footnotetext{
${ }^{45}$ Sauda Waliulu, S.Ag, M.Pd, Guru Pendidikan Agama Islam Kelas VIII MA Al-Fatah Ambon, Wawancara tanggal 17 Desember 2018.
} 
kompetensi yang akan dibentuk. Dalam beberapa situasi mungkin guru akan menemukan tersedinya materi yang banyak tetapi tidak terarah secara langsung pada sasaran yang ingin dicapai. Untuk itu, jika materi yang tersedia dirasakan belum cukup maka guru dapat menambah sendiri dengan memperhatikan strategi dan efektifitas pembelajaran. Pemahaman guru terhadap pemilihan dan penentuan materi menuntut guru untuk juga mampu dalam melaksanakan tindak lanjut ketika materi yang diajarkan belum cukup memahamkan peserta didik. Pemberian tindak lanjut yang dilakukan oleh guru tidak terlepas dari pemahaman guru yang mendalam terhadap materi yang diajarkan.

b. Mengorganisasikan materi pelajaran

Seorang guru dituntut untuk menjadi ahli penyebar informasi yang baik, karena tugas utamanya antara lain menyampaikan informasi kepada peserta didik. Disamping itu, guru juga berperan sebagai perencana (designer), pelaksana (implementer), dan penilai (evaluator) materi pelajaran. Apabila pelajaran diarahkan untuk memenuhi kebutuhan pribadi peserta didik dengan penyediaan ilmu yang tepat dan latihan ketrampilan yang mereka perlukan, haruslah ada ketergantungan terhadap materi pelajaran yang efektif dan terorganisasi. Untuk itu, diperlukan peran dari para guru untuk memiliki ketrampilan teknis yang memungkinkan untuk mengorganisasikan bahan pembelajaran serta menyampaikannya kepada peserta didik dalam proses pembelajaran.

Berdasarkan penjelasan di atas memberikan indikasi yang kuat bahwa guru hendaknya mempunyai kemampuan untuk mendesain pembelajaran baik itu yang berkaitan dengan materi, teknik, metode, media serta evaluasi belajar. Gambaran kemampuan guru pendidikan agama Islam di MA Al-Fatah Ambon terkait dengan kemampuan mengurutkan materi pelajaran dapat dilihat dari kemampuan guru ketika menyusun rencana program pembelajaran yang termasuk di dalamnya kemampuan menyusun rencana pembelajaran, kemampuan menyusun silabus, kemampuan melakukan evaluasi, kemampuan melaksanakan tindak lanjut.

Kemampuan guru dalam menyusun rencana pembelajaran memberikan indikasi tentang kemampuan guru mengorganisasikan materi pelajaran karena dalam penyusunan rencana program pembelajaran guru mampu menyusun standar 
kompetensi dan kompetensi dasar yang dikembangkan dalam standar isi dan standar kompetensi setiap kelompok mata pelajaran, menjabarkan SK, KD ke dalam indikator sebagai langkah awal untuk mengembangkan materi standar untuk membentuk kompetensi tersebut dan mengembangkan ruang lingkup dan urutan setiap kompetensi dimana materi pembelajaran tersebut disusun dalam tema dan sub tema atau topik dan sub topik yang mengandung ide-ide pokok sesuai dengan kompetensi dan tujuan pembelajaran. Dalam pembelajaran guru pendidikan agama Islam berpedoman pada RPP dan Silabus serta kurikulum yang dibuat, hal ini menggambarkan bahwa guru mampu mengorganisasikan materi pelajaran yang akan disampaikan melaui kelihaian guru dalam menciptakan rencana program pembelajaran, menciptakan silabus, dan dalam pelaksanaannya berpedoman pada RPP, silabus serta kurikulum yang telah di buat.

c. Mendayagunakan sumber belajar

Guru dituntut bukan hanya sekedar mendayagunakan sumber-sumber pembelajaran yang ada di madrasah seperti halnya membaca buku ajar, akan tetapi dituntut untuk mempelajari berbagai sumber seperti majalah, surat kabar, internet, televisi dan radio.

Sebagaimana dijelaskan pada penjelasan di atas dalam pembahasan mengenai kompetensi pedagogik salah satunya kemampuan guru pendidikan agama Islam menggunakan alat peraga dan pemanfaatan teknologi pembelajaran memberi gambaran bahwa ada sebagian guru yang mampu mendayagunakan sumber belajar seperti pemanfaatan teknologi informasi sebagai sumber belajar seperti yang dilakukan oleh Sauda Waliulu, bahwa:

untuk menarik peserta didik dalam belajar beliau membelajarkan peserta didik lewat media masa artinya peserta didik ditugaskan untuk belajar dari informasi yang mereka dapatkan di media masa kemudian dikaitkan dengan materi pelajaran yang dipelajari. Seperti halnya untuk mata pelajaran PAI beliau memberi tugas pada peserta didik untuk mencari informasi mengenai contohcontoh aklak yang baik dan akhlak tercela, permasalahan yang terjadi di masyarakat terkait dengan perilaku penyimpangan akhlak, kemudian peserta didik diperintahkan untuk memberikan argument ataupun refleksi terhadap 
informasi yang didapatkan dihubungkan dengan materi pelajaran PAI. Jadi dalam pembelajarannya peserta didik bukan hanya mendapatkan materi secara teoritis dengan penjelasan guru akan tetapi guru mampu mendayagunakan sumber belajar seperti media masa dalam pembelajaran. ${ }^{46}$

Berdasarkana uraian yang telah di paparkan di atas, maka dapat penulis simpulkan bahwa tidak semua guru pendidikan agama Islam di MA Al-Fatah Ambon mampu mendayagunakan sumber belajar sebagai alat pembelajaran, kebanyakan dari guru di madrasah ini hanya menggunakan buku bahan ajar, LKS sebagai sumber belajarnya. Padahal sumber belajar merupakan alat pembelajaran yang efektif memberikan pesan kepada peserta didik, sehingga membutuhkan kemampuan dan kelihaian dari pengelola pembelajaran dalam hal ini guru untuk mendayagunakan sumber belajar sebagai media yang akan membantu mempermudah guru dalam menyampaikan pesan pelajaran.

\section{e. Hasil Belajar Peserta didik}

Hasil belajar merupakan kata majemuk yang terdiri dari kata prestasi dan belajar. Hasil belajar ini merupakan salah satu alat ukur tingkat keberhasilan seorang peserta didik di dalam kegiatan proses belajar mengajar yang diikutinya di madrasah. Dengan demikian, seorang peserta didik mendapat hasil belajar minimal dalam batas rangking tertentu, sering dikatakan peserta didik tersebut berhasil. Kemampuan guru penting dalam hubungannya dengan kegiatan belajar mengajar dan hasil belajar peserta didik. Karena proses belajar mengajar dan hasil belajar yang diperoleh peserta didik tidak hanya ditentukan oleh madrasah, pola struktur dan isi kurikulum, akan tetapi juga ditentukan oleh kemampuan guru mengajar dan membimbing peserta didik. Guru yang profesional akan mampu menciptakan lingkungan belajar yang efektif dan menyenangkan serta mampu mengelola kelasnya sehinga hasil belajar peserta didik berada pada tingkat optimal.

Dengan demikina, maka hasil belajar merupakan tolak ukur keberhasilan guru dalam pembelajaran. Tingkat pencapaian prestasi belajar peserta didik menjadi

\footnotetext{
${ }^{46}$ Sauda Waliulu, S.Ag, M.Pd, Guru Pendidikan Agama Islam Kelas VIII MA Al-Fatah Ambon, Wawancara tanggal 17 Desember 2018.
} 
salah satu indikator keberhasilan proses belajar mengajar yang dilaksanakan oleh guru dan peserta didik. Seorang guru dapat juga dikatakan berhasil apabila guru tersebut mampu membawa peserta didiknya mencapai target kompetensi yang telah ditentukan.

\section{Faktor Pendudukung dan Penghambat Guru PAl Dalam Meningkatkan Hasil Belajar Peserta didik di MA Al-Fatah Ambon}

\section{a. Faktor Pendudukng}

Guru adalah tenaga pendidik yang mempunyai peran penting dalam pendidikan khususnya hal yang berkaitan dengan proses belajar mengajar. Mengajar adalah kemampuan profesional, karena mengajar tidak hanya membutuhkan pengembangan bakat mendidik, melainkan kegiatan yang harus ditunjang dan dilengkapi dengan kemampuan-kemampuan lain seperti kemampuan memilih dan menggunakan metode pengajaran yang efektif dan tepat. Mengajar adalah rangkaian kegiatan penyampaian bahan pelajaran kepada peserta didik agar dapat menerima, menggapai, menguasai dan mengembangkan bahan pelajaran itu.

Guru yang profesional adalah guru yang mampu menciptakan lingkungan belajar yang efektif dengan didukung sarana prasarana yang memadai serta kemampuan guru menggunakan media pendidikan yang tersedia di madrasah atau merancangkan media yang belum ada, gunanya adalah mempermudahkan peserta didik memahami, mengetahui dan menerapkan teori yang diajarkan kepadanya. Materi pokok yang dipaparkan kepada peserta didik tidak sekedar teori-teori dalam ranah pengetahuan dan pemahaman akan tetapi, guru harus mengkomunikasikan dalam ranah aplikasi.

Berkaitan dengan hal ini maka faktor pendukung profesionalitas guru Pendidikan Agama Islam di MA Al-Fatah Ambon adalah berusaha memberikan fasilitas yang menunjang. Hal itu sebagaimana yang ditegaskan oleh kepala madrasah, Murni Kabalmay, yang menyatakan bahwa:

Guru Pendidikan Agama Islam adalah tenaga pendidik yang mempunyai peranan sangat signifikan khususnya dalam pembentukan akhlak dan moral peserta didik. Oleh karena itu, dibutuhkan guru yang benar-benar memiliki 
keahlian dan kemampuan profesional dalam mengelola pembelajaran. Dalam hal ini MA Al-Fatah Ambon berusaha memberikan sarana prasarana yang menunjang profesionalitas Guru Pendidikan Agama Islam seperti halnya penyediaan sarana ibadah (masjid) di lingkungan madrasah yang mana diharapkan dengan adanya masjid di madrasah, Guru Pendidikan Agama Islam mampu memanfaatkannya sebagai labolatorium keagamaan. Artinya dengan adanya fasilitas ini, guru mampu memberdayakan masjid sebagai sarana belajar, praktek dan pusat kegiatan yang berkaitan dengan pembelajaraan materi keagamaan. Selain dari pada itu faktor lain yang mendukung profesionalitas Guru Pendidikan Agama Islam di MA Al-Fatah Ambon adalah kesempatan bagi para Guru Pendidikan Agama Islam untuk mengkuti kegiatan-kegiatan yang menunjang kualitas guru seperti pelatihanpelatihan guru, seminar baik tingkat kota maupun tingkat propinsi, workshop serta peningkatan standar kompetensi guru sebagaimana salah satu terobosan yang sedang dilakukan pemerintah yaitu program sertifikasi guru. Melalui kegiatan-kegiatan ini diharapkan mampu menjadi faktor yang mendukung profesionalitas guru khususnya guru pendidikan agama Islam di MA Al-Fatah Ambon. ${ }^{47}$

Pernyataan tersebut di atas menggambarkan bahwa madrasah ini berusaha memberikan fasilitas yang mendukung bagi Guru Pendidikan Agama Islam untuk senantiasa tertuntut keprofesionalannya dalam mengelola pelajaran. Sehinga proses belajar mengajar bukan sekedar pemaparan teori-teori akan tetapi guru harus mengkomunikasikan dalam ranah aplikasi. Sehubungan dengan hal ini, sebagaimana peneliti temukan di lapangan sebagian Guru Pendidikan Agama Islam di madrasah ini sudah tidak lagi menyampaikan materi agama secara teoritas saja akan tetapi melalui praktik dan aplikatif. Sebagaimana contohnya untuk materi-materi praktek keagamaan seperti tata cara sholat, praktek wudhu, sholat jenazah dan sebagainya pembelajarannya mereka lakukan di masjid madrasah. Selain dari pada

${ }^{47}$ Murni Kabalmay, S.Pd.I, Kepala MA Al-Fatah Ambon, Wawancara tanggal 22 Desember 2018. 
itu, Guru Pendidikan Agama Islam di madrasah ini membiasakan peserta didiknya untuk mengaplikasikan ilmu yang telah diperolehnya melalui penanaman kesadaran disiplin beribadah. Seperti halnya madrasah ini mewajibkan kepada seluruh peserta didiknya untuk, tadarus bersama waktu hari jumat pagi di madrasah.

Selain itu, faktor lain yang mendukung profesionalitas guru pendidikan agama Islam sebagaimana diungkapkan oleh Sauda Waliulu bahwa:

kesempatan yang besar untuk mengikuti kegiatan yang mendukung peningkatan kualitas profesionalitas guru salah satunya adalah melalui pelatihan-pelatihan, seminar dan program sertifikasi guru. Dalam rangka peningkatan kemampuan profesional guru yang dilakukan melalui kegiatankegiatan tersebut diharapkan agar guru kinerjanya terus meningkat dan tetap memenuhi syarat profesional. Melalui kegiatan-kegiatan inilah yang mendukung keprofesionalan Guru Pendidikan Agama Islam. ${ }^{48}$

Selain itu, faktor yang mendukung profesionalitas guru pendidikan Agama Islam sebagaimana wawancara penulis dengan kepala madrasah Murni Kabalmay adalah:

Faktor yang mendukung profesionalitas guru agama disini adalah kalau kita sudah menciptakan atau membuat kebijakan yang dilakukan oleh seluruh aparat madrasah, dalam hal ini adalah ketegasan kepala madrasah dalam memimpin. Artinya saya selaku kepala madrasah harus tegas dalam memimpin, dan ini tidak terlepas dari bagaimana saya selaku kepala madrasah mampu memberikan pendekatan yang intensif kepada individu seluruh komponen madrasah, dan kalau kepala madrasah sudah kenceng otomatis dengan sendirinya seluruh komponen juga akan tegas dalam menjalankan tugasnya. Selain dari pada itu faktor lain yang mendukung adalah manajemen madrasah yang baik, dalam hal ini bagian administrasi (TU) dan bagian perencana proses belajar mengajar (Kurikulum). ${ }^{49}$

\footnotetext{
${ }^{48}$ Sauda Waliulu, S.Ag, M.Pd, Guru Pendidikan Agama Islam Kelas VIII MA Al-Fatah Ambon, Wawancara tanggal 17 Desember 2018.

${ }^{49}$ Murni Kabalmay, S.Pd.I, Kepala MA Al-Fatah Ambon, Wawancara tanggal 22 Desember 2018.
} 
Berdasarkan keterangan di atas, jelas bahwasannya suatu lembaga pendidikan membutuhkan pengelola atau pemimpin yang bertindak sebagai polisi. Pemimpin adalah seseorang yang mengatur terlaksananya proses pembelajaran di madrasah, dan tercapainya tujuan yang telah dirumuskan sebelumnya. Pemimpin lembaga pendidikan adalah seseorang yang dapat menciptakan, mengorganisasikan, memengawasi proses pembelajaran agar terlaksana dan tercapai tujuan pembelajaran.

Sehubungan dengan pendapat di atas, bahwa gaya kepemimpinan kepala madrasah sebagai manajer madrasah sangat erat kaitannya dengan faktor yang mendukung profesionalitas guru pendidikan agama Islam di MA Al-Fatah Ambon, bahwa pola kepemimpinan kepala madrasah hendaklah disesuaikan dengan kematangan dan kemampuan bawahan. Dalam hal ini kepala madrasah berperan serta memberikan kesadaran kepada seluruh komponen madrasah berkaitan dengan kesadaran menerima tugas dan tanggung jawab dan menjalankannya secara profesional.

\section{b. Faktor Penghambat}

Mengenai faktor yang menghambat profesionalitas Guru Pendidikan Agama Islam di MA Al-Fatah Ambon, Murni Kabalmay, selaku Kepala Madrasah mengatakan bahwa:

Kalau faktor yang menghambat guru tidak profesional dalam menjalankan tugas mengajarnya di madrasah ini adalah ada sebagian guru yang kehadirannya tidak full time di MA Al-Fatah Ambon, ada sebagian guru yang hadir di madrasah hanya untuk mengajar saja setelah jam mengajar selesai maka guru tersebut langsung pulang, selain dari pada itu ada guru yang usianya mendekati pensiun sehinga mulai ada penurunan kerja. ${ }^{50}$

\footnotetext{
${ }^{50}$ Murni Kabalmay, S.Pd.I, Kepala MA Al-Fatah Ambon, Wawancara tanggal 22 Desember 2018.
} 
Berdasarkan pernyataan di atas, terang bahwa faktor utama yang menghambat profesionalitas guru dalam menjalankan tugas mengajar peran serta guru yang tidak full time di madrasah serta penurunan kinerja guru karena faktor usia yang sudah lanjut. Hal demikian itu semestinya bukan merupakan suatu alasan bagi seorang guru untuk tidak berperilaku secara profesional terlebih dalam proses pembelajaran karena guru adalah merupakan tenaga pendidik yang dituntut secara moral mampu bertanggung jawab terhadap berhasilnya pendidikan. Walaupun tugas guru tidak $100 \%$ waktunya mengajar namun pekerjaan mengajar adalah pekerjaan utama dan perlu dilaksanakan secara profesional.

Tujuan yang hendak dicapai seorang yang profesional adalah tujuan yang jelas dan transparan. melakukan prosedur, mekanisme yang tepat akurat sehingga hasil suatu pekerjaan kelak dicapai dengan penuh kepuasan. Bagaimana mungkin seorang guru dapat secara profesional kalau pada kenyataanya guru tidak secara maksimal menjalankan tugas mengajarnya. Sebagaimana hasil observasi yang peneliti temukan di lapangan bahwa ada sebagian guru di MA Al-Fatah Ambon yang belum menekuni profesinya secara utuh. Hal ini disebabkan oleh sebagian guru yang bekerja di luar jam kerjanya sehingga tidak secara maksimal berada di madrasah. ${ }^{51}$

Sebagaimana yang diungkapkan oleh Murni Kabalmay bahwa:

Kalau faktor yang menghambat guru tidak profesional dalam menjalankan tugasnya adalah karena kurangnya kesadaran (sumber daya manusia) dalam individu guru itu sendiri padahal sebagai guru sudah semestinya guru itu paham bahwa seharusnya tertuntut untuk profesional dalam bekerja sehingga kalau ada guru yang kurang profesional dalam mengajar maka akan mempunyai pengaruh besar terhadap guru lain, sehingga dapat menghambat kinerja guru lain. Selain dari pada itu, faktor ekstern yang menghambat adalah ada sebagian guru yang nyabang (mengajar di tempat lain) yang mana dengan keadaan yang seperti inilah yang mengurangi keprofesional guru dalam menjalankan tugasnya. ${ }^{52}$

\footnotetext{
${ }^{51}$ Hasil Observasi di MA Al-Fatah Ambon pada tanggal 12 Desember 2018.

${ }^{52}$ Murni Kabalmay, S.Pd.I, Kepala MA Al-Fatah Ambon, Wawancara tanggal 22 Desember 2018.
} 
Dengan demikian, maka dapat disimpulkan bahwa untuk memenuhi persayaratan guru yang profesional hendaklah seorang guru mampu secara maksimal menjalankan tugas keprofesionalanhya bagaimana mungkin seorang guru dikatakan profesional apabila guru belum maksimal mendampingi peserta didik, guru hanya hadir untuk menyelesaikan tugas mengajarnya sedang pemahaman, pembinaan dan bimbingan terhadap peserta didik kurang dilaksanakan sepenuhnya oleh guru. Pembelajaran akan secara mudah dilaksanakan oleh kedua belah pihak (pendidik dan peserta didik) apabila ada rasa saling memahami satu sama lain dan untuk mencapai kesepahaman guru dituntut loyal terhadap tugas pendidikannya.

\section{KESIMPULAN}

Berdasar pada temuan data di lapangan dan sebagaimana dipaparkan dalam bab-bab terdahulu terkait dengan profesionalitas guru PAI dalam meningkatkan hasil belajar peserta didik di MA Al-Fatah Ambon, maka dapat diambil kesimpulan sebagai berikut:

1. Profesionalitas guru pendidikan agama Islam di MA Al-Fatah Ambon digambarkan dalam kemampuan pedagogik, kemampuan kepribadian, kemampuan sosial dan kemampuan profesional, diman guru harus dapat dan kemampuan menguasai bidang studi dapat dilihat dari latar belakang pendidikan guru yang memiliki kualifikasi akademik dan latar belakang pendidikan sesuai dengan bidang tugas, kemampuan memahami peserta didik melalui pendekatan secara individual untuk mendiagnosis kesulitan dan permasalahan peserta didik sehingga. Selain itu untuk meningkatkan profesionalitas kinerjanya dengan mengikuti pelatihan-pelatihan, seminar, work shop dsb. Apabila guru sudah profesional otomatis prestasi peserta didik juga akan meningkat. Dengan asumsi bahwa guru yang mempunyai ketrampilan mengajar yang baik akan dapat melaksanakan proses belajar mengajar dengan baik pula. Oleh karena itu makin profesional guru yang mengajar maka makin baik pula prestasi belajar peserta didik. 
2. Berkenaan dengan faktor yang mendukung profesionalitas guru PAl dalam meningkatkan hasil belajar peserta didik di MA Al-Fatah Ambon adalah adanya pengawasan yang ketat dari kepala madrasah sehingga mentidakibatkan guru berdisiplin, diberlakukannya manajemen yang berbasiskan pada madrasah (MBM), terbentuknya tertib administrasi yang rapi, dan diikutkannya guru PAI dalam berbagai acara sebagai upaya peningkatan profesionalitasnya. Sedangkan hal yang menghambat profesionalitas guru di madrasah ini adalah adanya sebagian guru yang hadir di madrasah hanya pada saat-saat jam mengajar atau tidak ful time. Sehingga hal ini mengganggu guru lainnya yang lebih baik (profesional).

Sebagai akhir dari penulisan ini maka dapat diajukan beberapa saran yang patut untuk diperhatikan kepada pihak-pihak yang bersangkutan terkait profesionalitas guru pendidikan agama Islam dalam meningkatkan hasil belajar peserta didik di MA Al-Fatah Ambon:

1. Kepala madrasah memposisikan peranannya sebagai leader yang mempimpin dan menentukan kebijakan ruang gerak seluruh proses yang terjadi di lembaga madrasah dan sebagai supervisor pendidikan yang bertanggung jawab mengevaluasi program dan hasil pendidikan. Oleh karena itu, untuk meningkatkan kualitas madrasah yang baik hendaklah kepala madrasah juga meningkatkan potensi dan kualitas seluruh elemen madrasah yaitu melalui peningkatan profesionalitas kinerja.

2. Kepada guru pendidikan agama Islam hendaklah sadar akan peranan dan fungsinya dimana guru harus lebih memperhatikan profesionalitasnya karena merupakan tanggungjawab dan memiliki orientasi dunia akhirat. Artinya guru bukan hanya bertanggung jawab memintarkan peserta didik secara intelektual (transfer of knowledge) akan tetapi, guru juga mempunyai tanggungjawab menanamkan nilai dan moral (transfer of value). Oleh karena itu, tanggungjawab ini menuntut guru untuk senantiasa profesional dalam kinerjanya.

3. Rekomendasi penelitian yang nantinya perlu untuk dilakukan penelitian lanjutan adalah mengenai motivasi profesionalitas guru pendidikan agama Islam yang 
mana perlu untuk melakukan kajian lebih lanjut mengenai apa dan bagaimana motif dari guru pendidikan agama Islam bertindak profesional dalam kinerjanya.

\section{DAFTAR PUSTAKA}

Abdul Majid \& Dian Andayani, Pendidikan Agama Islam Berbasis Kompetensi, Konsep dan Implementasi Kurikulum 2004 (Cet. II; Bandung: PT Remaja Rosdakarya, 2005), hlm. 132

Dedi Supriyadi, Mengangkat Citra dan Martabat Guru, (Yogyakarta: Adicita Karya Nusantara: 2002), h. 39.

Departemen Agama RI, UU RI Thlm.2005 tentang Guru dan Dosen serta UU RI No.20 Thlm.2003 tentang SISDIKNAS), hIm. 56

E. Mulyasa, Standar Kompetensi dan Sertifikasi Guru, (Bandung: PT Remaja Rosdakarya, 2007), h 138.

Hery Noer Aly, IImu Pendidikan Islam (Cet. II; Jakarta: Logos, 1999), hlm. 16

HM. Arifin, Filsafat Pendidikan Islam (Cet. IV; Jakarta: Bumi Aksara, 2004), hlm.100

Lexy J. Moleong, Metodologi Penelitian Kualitatif, (Bandung: Remaja Rosdakarya, 2004, hlm. 4.

Mohlm. Uzer Usman, Menjadi Guru Profesional (Cet. XX; Bandung: Remaja Rosydakarya, 2006), hlm.19

Muktar dan A.Priambodo, Mengukir Prestasi Panduan Menjadi Guru Profesional, (Jakarta: CV. Misaka Galiza, 2001), hlm. 29.

Murni Kabalmay, S.Pd.I, Kepala MA Al-Fatah Ambon, Wawancara tanggal 12 Desember 2018.

Nanang Fattah, Landasan Manajemen Pendidikan, (Bandung: Remaja Rosydakarya: 2004. 
Sugiyono, Metode Penelitian Kuantitatif dan Kualitatif dan R \& D, (Bandung: CV. Alfabeta, 2012), hlm. 240.

Undang-Undang SISDIKNAS UU RI No.20 Th.2003 pasal 8 butir d, hlm. 82. 